\title{
ШЛЯХИ ФОРМУВАННЯ ДУХОВНО-ІНТЕЛЕКТУАЛЬНИХ ЦІННОСТЕЙ ДОРОСЛИХ
}

\author{
А. В. Боярська-Хоменко \\ к. пед. н., доцент кафедри історії і порівняльної педагогіки, \\ Харківський національний педагогічний університет імені Г. С. Сковороди
}

В умовах сучасного розвитку української держави ми часто відзначаємо пробудження цікавості суспільства до проблем морально-інтелектуального виховання дітей, до розвитку їх культурної обізнаності та становлення як громадян. Нині дитяча особистість $є$ центом уваги як з погляду педагогічної та психологічної науки, так і $з$ погляду суспільства і держави.

Сьогодні в Україні активними є процеси «осучаснення» та «глобалізації» освітнього процесу. Але у цій «гонці наввипередки», чи краще сказати «навздогін» за розвиненими країнами світу ми, українці, втрачаємо свої моральні та інтелектуальні цінності, часто ігноруємо перевірені часом форми та методи морального виховання підростаючого покоління, нав'язуючи дітям запозичену та часто не актуальну для нас духовну, інтелектуальну, культурну продукцію.

Як наслідок, стан культури та моральності нашого суспільства оцінюється вкрай низько, ба навіть катастрофічно. I це при такому багатому та невичерпному духовному потенціалі нашої нації, котрий ми накопичували десятками і сотнями поколінь. Масова безкультурність $\epsilon$ причиною багатьох негараздів у соціальному житті суспільства, в політичному розвитку країни, в катастрофічній екологічній ситуації.

Ми, педагоги, часто говоримо про моральне, духовне та інтелектуальне виховання дітей, але, нажаль, часто не зважаємо на проблеми розвитку моральності й духовності серед дорослого населення нашої країни. Ми вбачаємо в цьому прямий причинно-наслідковий зв' язок: дорослі люди з низьким духовно-інтелектуальним рівнем розвитку не можуть виховати високоморальне покоління.

Занепад моралі, жорстокість, зростання злочинності та насильства — все це є наслідком бездуховності дорослих. Некультурний лікар байдужий до страждань хворого, некультурний людина байдужа до творчих пошуків художника, некультурний будівельник будує пивний кіоск на місці скверу, некультурний землероб спотворює землю... Замість рідної української мови, яка визнана однією із найбільш милозвучних, — мова, засмічена іноземними словами, жаргонними фразами, а то й нецензурною лайкою. Сьогодні під загрозою руйнування того, що століттями створювали інтелект, дух та талант нашої нації — руйнуються старовинні міста, гинуть книги, архіви, твори мистецтва, втрачаються народні традиції майстерності.

Сьогодні всі говорять про необхідність освіти впродовж життя, про оволодіння цифровими та мовними компетенціями, про постійне підвищення свого інтелектуального розвитку. Разом з тим ми хочемо наголосити на важливості розвитку саме духовно-моральних цінностей дорослих українців. Адже саме дорослі люди (батьки, бабусі, дідусі, вчителі) закладають фундамент моральності, духовності та культури в підростаюче покоління. Але якщо вони самі не можуть похвалитись такими чеснотами, то як же ми можемо вимагати це від дітей, котрих вони виховають?!

Варто зазначити, що питання розвитку духовних та інтелектуальних цінностей дорослих підіймаються у сучасній науково-педагогічній літературі. Зокрема О. Целякова вивчала питання сучасного духовного стану українського суспільства, який вона охарактеризувала як мімікрію духовності, при якій традиційні цінності змінюють свій зміст або втрачають його взагалі [5]. О. Шкіренко у своїх наукових доробках доводив, що розвиток духовних цінностей дорослих є основою розвитку духовного потенціалу молоді [6]. С. Донець розкриває основні наукові підходи до розуміння феномену духовного розвитку особистості та особливості переживання кризових періодів онтогенезу, а також аналізує ймовірність, характер та особливості взаємозв'язку духовного розвитку людини та її нормативної кризи входження у дорослість [3]. Ю. Бурцева розкрила психолого-педагогічні засади духовного виховання в сім'ї та розглянула питання ролі сім’ї в морально-духовному вихованні дітей та молоді [2].

Але разом з тим, у науково-педагогічній літературі не достатньо розробленими та обгрунтованими залишаються практичні аспекти реалізації ідеї духовно-інтелектуального розвитку дорослих.

Метою нашого наукового дослідження $є$ визначення шляхів формування та розвитку духовно-моральних цінностей у процесі здійснення неперервної освіти дорослих.

Завдання дослідження полягають у доведенні актуальності розвитку духовних цінностей дорослих українців, вивченні позитивного досвіду країн Центральної та Східної Європи у питаннях духовно-інтелектуального навчання дорослих, розробці практичних шляхів творчого застосування досвіду країн Свропи у питаннях формування та розвитку духовних цінностей дорослих.

У дослідженні використано загальнонаукові методи: індукція та дедукція, аналіз і синтез, аналогія, узагальнення, систематизація та класифікація - для формування понять дослідження, виявлення сутнісних ха- 
рактеристик духовно-моральних цінностей, провідних тенденцій розвитку питань формування духовності дорослих. Також використано компаративний метод — для розгляду спільного і відмінного в організації навчання дорослих у країнах Свропи та Україні. Методи прогнозування й моделювання використовувались з метою окреслення перспектив використання досвіду країн Центральної та Східної Свропи у питаннях розвитку духовно-інтелектуальних цінностей дорослих в Україні

Аналіз літератури та нормативно-правових актів країн Центральної та Східної Свропи показав, що вказати точні межі періоду дорослості досить складно. Це пояснюється тим, що дорослою вважається людина, котра не лише досягла певного біологічного віку, а й зазнала змін у способах мислення, поведінці, має певні чіткі цілі та установки, певний життєвий досвід та бере участь у трудовій діяльності й соціальному житті. Тобто серед провідних показників досягнення дорослості європейські дослідники визначають: біологічний вік; психологічну, фізичну та соціальну зрілість; громадянську дієздатність, що визнана державою й суспільством; залучення до трудової діяльності [1]. Розглядаючи загальносвітові нормативно-правові акти, слід відзначити, що на генеральній сесії ЮНЕСКО 1976 р. у Найробі було у соціальному аспекті визначено поняття «доросла людина», як будь-яка людина, що визнана дорослою у тому суспільстві, до якого вона належить [4].

Для вирішення проблеми формування та розвитку духовно-інтелектуальних цінностей українців важливою $\epsilon$ організація освітнього процесу саме для дорослих. У цьому аспекті хочеться звернутись до позитивного досвіду країн Центральної та Східної Свропи. Так, Німеччина, Австрія, Словенія, Чехія, Польща активно впроваджують освітні програми для дорослих, котрі спрямовані на розвиток загальнолюдських моральних та культурних цінностей, але при цьому грунтуються на ідентичності та унікальності кожного народу.

Так, для прикладу, пропоную сьогодні поглянути на курси дистанційної освіти для дорослих у Німеччині. Поряд зі звичними для нас мовними, комп’ютерними, економічними, бізнесовими та менеджерськими освітніми курсами, заклади дистанційної освіти Німеччини пропонують низку курсів з етики для різних професій, курс соціології здоров’я, курси збереження емоційного та психологічного здоров’я дорослих, курси культурного розвитку тощо.

Метою створення подібних курсів є навчання дорослих людей умінням зважувати етичні цінності, вирішувати конфлікти та розуміти критичні ситуації. Грунтуючись на етичних принципах, курси навчають дорослих розуміти складні питання у професійній та особистій сфері, вирішувати етичні, правові та економічні аспекти повсякденного життя, відповідально ставитись до свого фізичного та емоційного здоров'я, а також спонукають дорослих людей до розширення власного кругозору та формування культурних цінностей. Цікавим $\epsilon$ те, що дистанційна освіта в Німеччині пропонує низку спеціальних курсів за різними напрямами: консультант по здоровому харчуванню, альтернативна медицина, психотерапія, сучасне та творче письмо у різних жанрах літератури, духовний розвиток особистості, астрологічна психологія тощо.

Курси для дорослих розроблено у дистанційному форматі, зареєструватись на них може кожен бажаючий, не зважаючи на попередній рівень освіти. Дистанційні курси розміщені на спеціальні освітній платформі. Варто зазначити, що знайти цікавий та актуальний для себе курс досить легко. Так, існує спеціальний портал дистанційної освіти, де зібрано освітні пропозиції від усіх закладів дистанційного навчання Німеччини. Відвідувач може обрати галузь, яка його цікавить, обрати навчальний заклад та регіон, тривалість та вартість навчання.

Тривалість курсів морально-інтелектуального та культурного розвитку становить від 2 до 4 місяців. Кожен зареєстрований учасник отримує вільний доступ до пакету необхідної літератури, забезпечується методичними матеріалами та отримує консультації від викладача. Наприкінці навчання кожен учасник отримує для виконання спеціально розроблене тематичне завдання, а у разі його успішного складання отримує офіційне підтвердження у вигляді сертифікату державного зразка.

Зважаючи на успішний досвід країн Центральної та Східної Свропи у питаннях формування і розвитку духовно-інтелектуальних цінностей дорослого населення, ми пропонуємо розробити дистанційні курси неформальної освіти дорослих. Курси можуть передбачати вивчення таких освітніх програм як етика у різних професійних галузях, психологія особистісного розвитку, культура та мистецтво, психологія та культурологія здоров’я, особисті духовні практики тощо.

Особливий аспект варто зробити на популяризації таких програм, адже більшість дорослого населення України залишається осторонь освітніх питань та не визнає важливості освіти впродовж життя та необхідності постійного особистісного й культурного заростання. Ми пропонуємо створити портал дистанційної освіти дорослих, котрий би об’єднав різні навчальні заклади та освітні програми для оптимізації процесу пошуку, реєстрації та зарахування на освітні курси.

Разом $з$ тим, наступним кроком повинно стати створення спеціального супроводу здобувача освіти впродовж всього періоду навчання, а також розробити спеціальне «Керівництво з дистанційного навчання», у якому викладена важлива інформація щодо особливостей навчання та інструкція для здобуття освіти у дистанційній формі.

Звісно, для реалізації запропонованих завдань необхідним є створення центрального управління дистанційної освіти. В Україні це повинен бути загальнодержавний орган, який забезпечуватиме якість та прозорість 
системи дистанційної освіти, розроблятиме і затверджуватиме стандарти якості навчальних курсів. Разом 3 тим, створення центральної дистанційної освіти дорослих забезпечить можливість офіційного визнання дистанційної та неформальної освіти дорослих та підтвердження ії рівня документами державного зразка.

Таким чином, підсумовуючи сказане вище, хочеться ще раз наголосити на тому, що духовний та моральний розвиток дітей прямо пропорційно залежить від рівня духовного та морального розвитку дорослих. I ми, педагоги, повинні сьогодні своїм прикладом переконати українське населення у необхідності постійного особистісного зростання, у доцільності формування та розвитку, перш за все, своїх духовних цінностей та високоморальних переконань.

Для реалізації ідеї розвитку духовно-інтелектуальних цінностей дорослих ми пропонуємо такі шляхи: створення дистанційних курсів з етики для різних професій, курсів соціології здоров’я, курсів збереження емоційного та психологічного здоров'я дорослих, курсів культурного розвитку тощо; забезпечення вільного доступу усіх категорій дорослого населення до проходження таких курсів духовно-інтелектуального розвитку; популяризація ідеї неперервного навчання серед дорослих українців; забезпечення спеціального супроводу здобувачів освіти впродовж всього періоду навчання; створення центрального управління дистанційної освіти.

Серед перспектив подальших досліджень ми вбачаємо вивчення дидактичних та методичних питань формування і розвитку духовно-інтелектуальних цінностей у процесі навчання дорослих.

\section{Література}

1. Боярська-Хоменко А. В. Визначення поняття «дорослість» у країнах Центральної та Східної Свропи // Збірник наукових праць Харківського національного педагогічного університету ім. Г. С. Сковороди «Теорія та методика навчання та виховання». Харків, 2018. Вип. 44. с. 29-43

2. Бурцева Ю. О. Роль сім’ї у формуванні духовно-моральної особистості // Духовність особистості: методологія, теорія і практика. Вип. 4 (79). 2017. с. 70-77

3. Донець С. І. Духовний розвиток особистості у кризі входження у дорослість (теоретичний анал із питання) // Науковий часопис Національного педагогічного університету імені М. П. Драгоманова. Серія 12 : Психологічні науки : зб. наук. праць. Київ : Вид-во НПУ ім. М. П. Драгоманова, 2018. Вип. 7 (52). С. 32-38.

4. Рекомендация о развитии образования взрослых, принятая Генеральной конференцией на ее 19-й сессии, Найроби, 26 ноября 1976 г. Париж: ЮНЕСКО, 1976.

5. Целякова О. М. Духовність і ціннісні орієнтації студентської молоді України в трансформаційному суспільстві // Гуманітарний вісник ЗДІА. Вип. 38, 2009. С. 233-222

6. Шкіренко О. В. Духовні цінності дорослих - основа розвитку духовного потенціалу молоді // Освіта дорослих: теорія, досвід, перспективи. 2015. Вип. 2. С. 61-69. 